San José Rico, Patricia. "The writer as translator: Langston Hughes and his transcultural racial interpretation of the Spanish Civil War". In: New Approaches to Translation, Conflict and Memory - Narratives of the Spanish Civil War and the Dictatorship. Palgrave Macmillan. 2019, p. 23-43. ISBN 978-3-030-00697-6 / 978-3-030-00698-3

\title{
The writer as notional translator: Langston Hughes and his transcultural racial interpretation of the Spanish Civil War. ${ }^{1}$
}

According to his autobiographical volume I Wonder as I Wander, when Langston Hughes left Spain after covering for the Baltimore Afro-American (an American periodical) its civil war conflict across six months from July to December 1937, he had serious problems packing and carrying around all of the belongings he had collected during his time there. Even though he left behind his phonograph records for his friends in Madrid to play 'Organ Grinder's Swing' (among others) during bombings in order to drown out, like he had done before, the explosions outside, Hughes insisted on taking with him a good deal of souvenirs that he had collected during his stay. Consequently, his friend and Cuban writer Nicolás Guillén saw himself forced to help him carry a series of miscellaneous objects including a bottle of wine in a wicker basket, a pair of bullfight banderillas, a box with shrapnel fragments, and a lace mantilla as well as dozens of gift books "warmly inscribed” by their authors (Hughes 1993, p.394). It is easy to imagine that, besides all those tangible objects, Hughes was taking with him much more, and that, by the same assumption, he also left behind more than a bunch of music records. Memories and intangible experiences usually accompany those who experience them and Langston Hughes no doubt brought a great deal of those back home with him.

And yet, even if Hughes's material luggage was ostensibly smaller on his way to Spain, his emotional and life baggage was already voluminous and filled with the knowledge and experience of racial oppression and segregation in the US, which, as the

\footnotetext{
${ }^{1}$ This article has been elaborated thanks to the financial support of the Spanish Ministerio de Economía y Competitividad (Research Project: "Historia Crítica de la Literatura Étnica Norteamericana: Una Aproximación Intercultural” (FFI2015-64137-P)) and the Junta de Castilla y León (Research Project: “Las Fronteras de la Hospitalidad en los Estudios Culturales de Estados Unidos y Europa” (SA342U1)).
} 
texts analyzed here amply prove, permeated his experience and-perhaps most importantly_his representation of the Spanish conflict. In that sense, most of Hughes's production during or about the Spanish Civil War can be understood as a cultural translation practice, even if not a literal one. Just as Evelyn Scaramella reminds us, “[t]he Latin word for 'translation,' translatio, means ‘to carry across' (2014, p.178), which underlines the transnational and transcultural aspect of translation in what I understand to be a bidirectional motion. Translators not only bring the experience of a foreign language, culture and literature back to their own languages, cultures and literatures, but they also unavoidably take with them their own exposures to their home backgrounds and transfer them unto their understanding of the host culture. In this sense, writers such as Langston Hughes, even when not undertaking translation projects in its strictly linguistic sense, can be understood to perform an act of cultural translation, which Laura P. S. Izarra defines as "the result of the contact between two or more cultures where both cultures provoke transformations in each other” (2004, p.343). Although Hughes does undertake both types of translation in relation to the Spanish conflict, he devotes much more time and space to the latter, interpreting the Spanish situation from the point of view of his American experience and vice versa.

What is more, insomuch as the metaphorical luggage that Langston Hughes was carrying with him on his way to conflicted Spain was already and in itself an experience of a struggle, he truly became a translator of conflict in the sense that he transferred his first-hand knowledge of the racial confrontation and fight for equality in the US into his understanding of the Spanish War. However, that transference did not occur in a single direction. In what follows, excerpts of Langston Hughes's writings (both articles and poems) produced during or about the Spanish Civil War will be used to demonstrate that not only did he filter what he learnt of the Spanish conflict through his personal 
experience of race and politics acquired in his native country, but he also utilized certain aspects of the war he was witnessing and attesting to, thus explaining and putting in perspective his fellow African Americans' struggle back at home. This way, Hughes became a mediator between the two countries, cultures and conflicts not only from a linguistic point of view (he could speak fluent Spanish and indeed actively worked as an interpreter between several English-speaking comrades and Spanish soldiers and villagers during the conflict), but also culturally.

According to William Scott, Walter Benjamin’s concept of translation highlights the fact that "what is really at stake in translation [is] the expression, not the reproduction, of a [...] specific significance [...] not reducible to the information conveyed in the meaning of individual words of sentences, but [...] rather an 'essential quality’ [...] of the literary work and thus not directly communicable as such” (2005: 38. Emphasis in the original). Taking this into account, together with the Latin etymology of the word translation, we must conclude that what Hughes is doing when he is not actually translating texts from one language to another but producing English texts about his Spanish experience is yet another form of translation; one that expresses the specific significance of the Spanish situation and transports it to the American sphere. The cultural type of translation carried out by Hughes, therefore, must be understood as his constantly conveying several cultural, notional and political ideas back and forth between both countries and backgrounds in the articles and poems he produced for the American public during or about the Spanish Civil War.

\section{Langston Hughes and the racial conflict as a global issue.}

That Hughes’s writings about Spain were filtered through the prism of race should not 
come as a surprise if we take into account the fact that he was sent to the conflicted country as a reporter for the Baltimore Afro-American "to cover for that paper the activities of Negroes in the International Brigades” (Hughes 1993, p.315) and that, moreover, he had strived from the earliest stages of his literary production to present himself as "a young writer deeply committed both to creating art and to theorizing the means by which art might merge with race to challenge and revise dominant conceptions of both” (De Santis 2013, p.106). As such, all of Hughes's literary productions should be taken as a translation act, for if we take into account Nicolás Guillén’s rendering of Hughes’s own words, he once claimed the following: "I have no other ambition than to be the poet of the Negroes . . . the blows they get hurt me to the core and I sing their sorrows, I translate their sadness, I put their anxieties to flight” (Guillén, qtd. Scott 2005: 59. Emphasis in the original).

A renowned member of the Harlem Renaissance in which race was at the core of most African American writers' production, Hughes saw several of his works published in The Crisis, the official publication of the NAACP (National Association for the Advancement of Colored People). The publication was, at that time, synonymous with the figure of W. E. B. Du Bois and his advocacy for African American writers to devote their literary production to racial issues and their community's plight, and the articles and short stories published there showcased his philosophy. Hughes no doubt also shared Du Bois' opinion and expressed it so in several of his essays, claiming for instance that "until America has completely absorbed the Negro and until segregation and racial self-consciousness have entirely disappeared, the true work of art from the Negro artist is bound, if it have any color and distinctiveness at all, to reflect his racial background and his racial environment” (Hughes, quoted in De Santis 2013, p.114. Emphasis in the original). Even though it is fair to say that Hughes's lighter skin colour 
and relatively comfortable economic situation (specifically during his most successful period as a writer) protected him from the harshest forms of racial discrimination, he certainly had internalized the racial struggle in a way that became (as for the majority of the African American community) part of his collective and personal identity, thus making him feel a responsibility to showcase his community’s plight in all his literary and essayist production, including the one dealing with the Spanish Civil War.

That Hughes considered himself spokesperson for the African American experience is made even more evident when we examine his words during a speech he gave as a delegate from the United States in the Second International Writers' Congress held in Paris in July 1937, days before he entered Spanish borders to cover its conflict:

I come to the Second International Writers Congress representing my country, America, but most especially the Negro peoples of America, and the poor peoples of America-because I am both a Negro and poor. And that combination of color and poverty gives me the right then to speak for the most oppressed group in America, that group that has known so little of American democracy, the fifteen million Negroes who dwell within our borders. (Hughes 1937, p.272)

This commitment to represent the racial cause coincides, moreover, with the peak of Hughes's political approach to Communism, which places him in direct ideological opposition to the rise of fascist regimes in Europe at the time. Fascism and racial oppression appear as natural synonyms in Hughes's mind and rhetoric. He continues his speech at the Second International Writers' Congress by clearly linking these two concepts: 
We [Negroes in America] are the people who have long known in actual practice the meaning of the word Fascism ... Yes, we Negroes of America do not have to be told what Fascism is in action. We know. Its theories of Nordic supremacy and economic suppression have long been realities to us. And now we view it on a world scale: Hitler in Germany with the abolition of labor unions, his tyranny over the Jews, and the sterilization of the Negro children of Cologne; Mussolini in Italy with his banning of Negroes on the theatrical stages, and his expedition of slaughter in Ethiopia; the Military Party in Japan with their little maps of how they'll conquer the whole world and their savage treatment of Koreans and Chinese; Batista and Vincent, the little American-made tyrants of Cuba and Haiti; and now Spain and Franco with his absurd cry of 'Viva Espana' at the hands of Italians, Moors and Germans invited to help him achieve 'Spanish Unity.' Absurd, but true. . . (Hughes 1937, p.272)

For Hughes, as Isabel Soto points out, “antiracism occupies the same discursive space as proletarian antifascism” (2014, p.133) and it does so in an international, diasporic sense. Global race issues certainly make their way into Hughes’s literary production in several instances, and he shows a marked tendency to equate the plight of racially marked communities of the world with that of his own. Just as Miller and Hubbard point out, "Hughes's astute perception of global linkages derived from a subconscious agreement with the concept of negritude- the idea that fulfilling the personal self becomes a conduit to a broader humanity” (2013, p.36). Such a global and transnational perception of race and humanity is broadly represented in his writings about the Spanish Civil War and is what lies at the core of his interpretation and translation of the conflict, as well as of his open adherence to the Republican cause and, probably, a weighty reason for his travelling to the conflicted country. His transference 
of the African Americans' experience of race and racism onto his representation of the Spanish Civil War and his liaising it with the rise of oppressive fascist regimes across Europe is to be understood as Hughes's attempt to draw a not so invisible line between the fight of his fellow racial comrades back at home and the menace to legal and civil rights in other belligerent countries. It is his translation of one conflict onto the other and vice versa as concurring with his view of all those rising (fascism) and already existing conflicts (racism) as one and the same.

\section{Langston Hughes as racial reporter in Spain.}

As aforementioned, Hughes went to Spain “to write for the colored press” (Hughes 2002c, p.161), and therefore he strived to describe in his dispatches as many coloured people as he could encounter in the divided country. And yet, as early on as in his second dispatch for the Baltimore Afro-American, he states that he does not want to write exclusively about the coloured people in the International Brigades; he is also very much interested in the Moors fighting for the fascist side, ${ }^{\mathrm{i}}$ as many of the articles and poems analyzed here demonstrate. In one of them, for instance, he affirms: "I knew that Spain once belonged to the Moors,” and continues: “[n]ow the Moors have come again to Spain with the Fascist armies as cannon fodder for Franco. But, on the Loyalist side there are many colored people of various nationalities in the International Brigades. I want to write about both Moors and colored people” (Hughes 2002c, p.161). According to Brent Hayes Edwards, references like this one to the prior existence of Moors in Spain and their connection to the presence of Moors in Franco's lines make reference to “a prior poetics of otherness within Spain itself," which might be considered "a species of translation on a formal level” (2007: 699). 
In his translational and diasporic take on race and racial matters, Hughes does not want to exclude any black people from his narrative of the war, and, as a consequence, he does not fail to filter what he sees through the lens of his own personal experience and ideology about race and world politics. We cannot forget that Hughes is but one of the numerous foreign writers that travelled to Spain as war correspondents in order to report back for their leftist magazines and newspapers the events taking place in that country. This was obviously done in an attempt to raise awareness of the Loyalists' cause back in their own countries and help raise money and volunteers for the International Brigades, so the writings they produced were heavily influenced by that political and ideological perspective. Just like other English-speaking writers such as George Orwell, Ernest Hemingway or W.H. Auden, among many others, Hughes no doubt felt that "writers and artists must translate for foreign audiences what they were witnessing in Spain in order to document their version of history” (Scaramella 2014, pp.184-187). That act of translation needs to be understood not (or not exclusively) as a linguistic act, but rather as a transference of ideological positions and personal experiences onto the writers' interpretation of the Spanish Civil War and vice versa. If we are to understand the literary production of these writers as, in the words of William Scott, "not concerned so much with realizing acts of communication or transmission [...] but with acts of expression of a specific socio-political significance that is not amenable to linguistic and discursive models of intelligibility” (2005: 38), then we must conclude that Hughes's literary and poetic production during the Spanish Civil War is a wilful act of cultural translation framed within a very specific socio-political context and performed with very specific socio-political purposes. Hughes, like the rest of the writers that travelled to Spain, felt that the only or most effective way in which they could join in what they saw as a global conflict was with the power of words and, 
consequently, they did not hesitate to apply their own thoughts and convictions to what they were witnessing in Spain and then relate that interpretation back to their previous ideological, cultural and socio-political purposes. In Hughes’s own words: "I am a writer, not a fighter. But that is what I want to be, a writer, recording what I see, commenting upon it, and distilling from my own emotions a personal interpretation” (Hughes 1993, p.400).

\section{Hughes as a cultural translator of conflict: Applying the American racial struggle to the Spanish Civil War and back.}

Because Hughes clearly equated the conflict of race in his own homeland to the Spanish Republican cause, his feelings towards the African Americans' participation in the Spanish Civil War were complex. He undoubtedly respected those volunteers that chose to fight in the International Brigades, but at the same time, he asked himself what would make an African American risk his life to solve the Spanish problems when there were so many (racial) problems still left unsolved back at home (Hughes 1993, p.354). That is: why abandon one conflict to join in another so far from home, so far from the struggle that affects them directly? Many of Hughes's writings during the period approach this issue, and he seems to conclude that fighting Fascism was felt as a moral imperative by those African Americans who identified the fascist ideology rising in Spain as intricately related to the ideology behind segregationist and racist practices taking place in their own homelands. As Isabel Soto points out, "the [Spanish] war presented an opportunity to oppose, literally to fight against racial othering. That the othering was being practiced by European colonial powers, such as Italy or Spain, rather than upholders of Jim Crow legislation was a false distinction” (2014, p.137). 
Hughes himself does not refrain from making similar connections in his weekly reports to the Baltimore Afro-American: "Give Franco a Hood and he would become a member of the Ku Klux Klan, a kleagle. Fascism is what the Ku Klux Klan will be when it combines with the Liberty League and starts using machine guns and airplanes instead of a few yards of rope” (2002g, p.181); or "The captured sniper turned out to be the vice president of the local Falangists, the town's Fascist organization (like our Ku Klux Klan)” (2002f, p.188). In another instance, shocked by the very recent death in action of an African American soldier he had expressly travelled to meet and pass on greetings from his brother whom Hughes had met back at home, he writes: "Milton Herndon had died not only to save another comrade, or another country, Spain, but for all of us in America, as well. You see, he understood the connections between the enemy at home and the enemy in Spain: They are the same enemy” (2002d, p.185). Hence the necessity to fight, the necessity to momentarily abandon the struggle against racial problems in the United States and join the Spanish cause, as it is perceived to be the same fight, the same struggle.

Hughes and the African American International Brigadiers he interviews consciously translate their domestic plights onto their Spanish experience, and consequently interpret the latter through that lens. But not only do they transfer their personal cultural and ideological background onto their understanding of their experience in Spain, they_in a true example of translation practice-apply their interpretation of the Spanish events to the problems they left back in their homeland. Thus, it is established a bidirectional motion very much like that of the translated text in which traces of both the target and original language's cultures are combined. This way, the target readers can find in a translated text a knowledge of the culture associated to that of its original language unavoidably permeated by the translator's personal 
understanding of that culture, which in turn emanates from his/her own cultural, economical and social background and coincides with that of the readers. Similarly, Hughes collects several manifestations of African American soldiers who believe that what they are living in the Spanish Civil War should be applied to their own situations at home; situations that, in turn, moved them to join the Spanish conflict and influence the way they view and interpret it.

However, as aforementioned, these African American soldiers do not limit themselves to translating their previous experiences onto the sphere of the Spanish Civil War; they translate their interpretation of the fight in Spanish soil back onto the struggle in America and wish to transfer the same fight there: "Colored college students must realize, too, the connection between the international situation and our problems at home" states one of the interviewees. And he continues: "When we see certain things happening in Europe and Asia that may involve America in another world war, then, and only then do we see clearly the need for combating such tendencies at home and abroad” (Hughes 2000b, p.195). This opinion resonates clearly in Hughes’s poem 'Song Of Spain' when he writes:

Workers, make no bombs again

Except that they be made for us

To hold and guard

Lest some Franco steal into our backyard

Under the guise of a patriot

Waving a flag and mouthing rot

And dropping bombs from a Christian steeple

On the people. (Hughes 1995e, vv. 63-70) 
Whereas the African American soldier places the responsibility of the Americansided fight on coloured college students, Hughes refers in this poem to workers of all races, perhaps coherently with his communist inclinations at the time. Just as in the above quoted speech for the Second International Writers' Congress he equates the end of Fascism with the victory of the "workers of the world," Hughes in 'Song Of Spain' exhorts the workers of the United States to not make bombs or bombing planes for fascist use and finishes the poem identifying Spain and its war with the workers' plight: “A workers’ world/Is the song of Spain” (Hughes 1995e, vv.82-83). Moreover, with that union of workers, he seems to imply, will come not only the end of Fascism, but the end of racism, as he sees those two concepts as one and the same: "When will we learn to work together like that in America?” He asks himself. "In Spain now the Internationals of all races stand against Fascism and its barbarous theories of white supremacy and working-class oppression. When the black and white workers of America learn to stand together in the same fashion, no oppressive forces in the world can hurt them” (2002a, p.187). In wishing this joining forces of peoples of all races against oppression that he witnesses in Spain to be transferred to America in the fight against racism, Hughes is effectively transferring one situation onto another, thus actively embarking on a process of notional if not linguistic translation.

\section{Black faces on the opposite side: an ideological and linguistic breach in Hughes's cultural translation act.}

But not only were there coloured people on the International Brigades; Hughes finds, much to his surprise and outrage, that Franco's troops are also utilizing black soldiers. Consequently, he writes extensively about what is, to his mind, a blatant oxymoron. Insomuch as, Luis Girón argues, "Hughes presents the [Spanish] war as an allegorical as 
well as historical conflict; he tends to equate the ideological struggle between democracy and fascism as a conflict between good and evil, (...) [he] was disturbed by the one component that did not fit into this neat arrangement of opposites: the North African troops serving with Franco's Army” (2005, p.97). The presence of black soldiers in the enemy's lines disrupts Hughes's ideological narrative and notional translation of conflicts and renders his argument for transferring to the US the racial unity against a common enemy he is portraying in Spain completely moot. “[U]nfortunately,” Hughes writes, "the Moors are shooting the wrong way. In pointing their guns against the workers and farmers of democratic Spain, they are only further aiding the rebel generals to tighten more surely their grip of despotism on Africa as well as on Spain” (Hughes 2002g, p.179).

When Hughes visited a hospital in which various wounded prisoners were being kept, he tried to talk to several of these Moors, but he finds that most of them cannot speak Spanish, thus linking Hughes’s linguistic inability to understand these men to his conceptual struggle to come to terms with the presence of black faces in the opposite side of the trenches. If we conceive translation as the process of making the incomprehensible understandable, then here it is failing. Hughes could not understand these wounded soldiers because he was unable to relate neither their words nor their actions into his own language and ideology.

This encounter is clearly the inspiration for what is (together with 'Song Of Spain') one of the better-known Hughes poems about the Spanish Civil War: 'Letter From Spain.' Taking the form of an epistle directed from the Lincoln Battalion of the International Brigades to an unnamed "Brother at home" in Alabama, the poem encapsulates Hughes's and the American soldiers' feelings of despair about fighting 
other coloured people (Girón 2005, p.97). The poem opens with the verbalization of these sentiments by the poetic voice of the African American soldier: "We captured a wounded Moor today,/He was just as dark as me./I said, Boy, what you been doin’ here/Fightin’ against the free?” (Hughes 1995b, vv. 2-5) and continues by expressing the previously mentioned experience of linguistic and conceptual inability to understand the boy and his role in the conflict: "He answered something in a language/I couldn't understand” (Hughes 1995b, vv.6-7). According to William Scott, the poem can be understood as embodying "a notion of translation that, from the very start, assumes the ultimate failure of linguistic intelligibility while insisting on the historical iterability, figured here as the material transliteration, of its international object: the dying body of the Moor” (2005: 56).

And yet, more than the linguistic barrier, it is the presence of dark faces among Franco's troops that baffles both Hughes and the poetic voice. Identifying himself on racial grounds with the wounded Moor on several occasions throughout the poem, the poetic voice reaches some understanding of the situation by explaining that the boy has been forcefully conscripted to fight on for the Republicans-an idea that Hughes also mentions repeatedly in his articles — and that "he [the Moor] didn't understand" (Hughes 1995b, p.37). Again, this lack of understanding on the part, this time, of the Moor referred to in the poem may be taken to refer both to the linguistic aspect of that Moor's exchange with the soldier and to Hughes's compassion towards these Africans on the grounds of his considering them “ignorant victims of Fascism” (Girón 2005, p.98). This same conclusion is also present in one of Hughes's reports about the Spanish Civil War published in the Volunteer for Liberty in September 1937. In it, Hughes refers to the African soldiers fighting under Franco's command as the “deluded and driven moors of Africa" and positions them "in the company of the professional soldiers of 
Germany, and the illiterate troops of Italy” (2002e, p.156). By pairing the adjective “deluded" with his portrayal of the Italian troops as "illiterate," Hughes seems to be emphasizing a notion of those African soldiers as either slaves or ignorant of the broader (racial) picture that Hughes strives to highlight in his argument. A similar judgment may be extracted from the very few Spanish poems on the Civil War that Hughes chose to translate.

The existence of these translations is not commonly known and it was not until very recently that they were discovered by Evelyn Scaramella. As it transpires from the article in which she explains the discovery, five poems written by Spanish authors and originally appearing in three separate volumes of poetry (Rafael Alberti's De un momento a otro (Poesía e Historia) 1932-1937ii and two compilations of poetry commissioned as propaganda by, respectively, the Alianza de Intelectuales Antifascistas $^{i i i}$ and the Spanish Republican ministry for Public Instruction about the Spanish Civil War (Poetas en la españa leal ${ }^{i v}$ and Romancero de la Guerra Civil) ${ }^{\mathrm{v}}$ ) were translated by Langston Hughes presumably during or shortly after his stay in Spain, although they were never published. These five poems are: Rafael Alberti's 'Dialoguillo de la revolución y el poeta,' ('A Little Dialogue Between The Poet And The Revolution'); José Moreno Villa’s 'Frente' ('Front'); 'Lamentación por los muchachos moros, que, engañados, han caído ante Madrid,' by Gil Albert ('Lament For The Young Moors'); another poem by Alberti, 'El moro fugado,' ('Moorish Deserter'); and Emilio Prados' 'El moro engañado'’ ('The Moor Betrayed') (Scaramella 2014, pp.182-184). Those translations were never published, so it is impossible to say whether or not they might have had an impact in the US or in Spain. Likewise, it is difficult to know whether the translation of these poems was part of an unfinished project between Alberti and Hughes ${ }^{\mathrm{vi}}$ to publicize and raise awareness for the Loyalist cause beyond 
Spanish borders during the conflict through an English translation of the three previously mentioned volumes, or if Hughes translated these poems for his own pleasure, or rather if they were translated with some other intention. What is noteworthy, however, is precisely the poems that were translated. Because only five translations have been found to date, and those pertaining to three separate volumes, we may be led to think that Hughes definitely had a hand on choosing the poems he wished to translate or, at the very least, on picking the order in which he wanted to translate them.

This hypothesis gains strength if we notice that, from the five poems, the latter three share the same topic: race, as they all deal with the participation of African soldiers under Franco's orders that had so baffled Hughes and to which he had dedicated so much attention in his articles and poems on the Spanish Civil War. It is remarkable, moreover, that in two of the Spanish titles for these poems appears the word engañado (which translates as betrayed or deceived) as referring to the Moors fighting by Franco’s side, and that in the third, the Moor has deserted Franco's ranks and surrendered to the Loyalist troops with the cry of "I’m with you, comrades!”vii (Scaramella 2014, p.184). This representation of Moors fighting for Nationalist forces as either deceived mercenaries or forcefully conscripted innocents is concordant with Hughes's own views, reflected in the poems and articles analyzed above, which gives us reason to believe that this is precisely why he felt attracted towards these poems.

\section{Fighting in Spain for racial freedom in the US: Bringing the luggage back home.}

Together with 'Letter From Spain,' Hughes wrote two more epistolary poems on the Spanish Civil War: 'Postcard From Spain’ and 'Love Letter From Spain.’ The first poem 
was originally composed during his time in Spain to be published in the Volunteer for Liberty, the journal of the International Brigades. The other two accompanied the former in its republication in the January $23^{\text {th }} 1938$ issue of The Daily Worker. All three poems are written in the form of letters sent by Johnny, an African American soldier fighting in the Lincoln Battalion of the International Brigades, to, respectively, his "Brother" (whether that brother is an actual sibling or an abstraction of all African Americans is open for discussion), his "Folks" and his "Sweetie” down in Alabama.

It is important to point out the fact that Hughes chose as metaphorical addressees for these three poems people living in Alabama, as that is one of the states in which segregation and racism was most acutely felt by African Americans at that moment. According to Isabel Soto, these specific addressees extend "the diasporic reach of the war in Spain to the 1861-65 conflict in a coalitional project that positions itself as a counter-discourse to the racial absolutism sweeping Spain and Europe at the time" (2014: 141). Consequently, all three poems address the Spanish Civil War through a racial lens and apply it back to the domestic American sphere in an attempt to "call for solidarity and internationalist consciousness” (Edwards 2007: 704). Consistent with Hughes’s repeated statement that “[i]n Spain there is no color prejudice” (2002e: 156), in 'Postcard From Spain' Johnny reflects on the fact that in Spain he is not being discriminated on the grounds of race (as his people are back at home), and expresses his hope that, in the future, there will be those who will be willing to fight for the rights of African Americans in the way that he is fighting now for the people of Spain:

Folks over here don't treat me

Like white folks used to do.

When I was home they treated me 
Just like they treatin’ you.

I don't think things'll ever

Be like that again:

I done met up with folks

Who'll fight for me now

Like I’m fightin' now for Spain. (Hughes 1995d, vv.10-18)

Since Hughes was defined by his own friend Nicolás Guillén as a poet whose production must be "understood as translation-specifically, as a translation that is the result of Hughes's observation, and thus as a translation which is to 'give' his people to be known [...] and to be loved as such (Scott 2005: 50. Emphasis in the original), this poem is precisely one clear example of that attempt of Hughes's to translate his people onto the Spanish situation by translating the Spanish situation to his people. This poem, therefore, is nothing other than the result of Hughes's observation of his people and recording of opinions during his stay in Spain, and his translation of those opinions and that people in order for them to be known and loved. That Johnny makes such direct reference to the situation of racial oppression back at home and links it to the fight against fascism in Spain situates this poem unequivocally within Hughes's and the interviewed colored soldiers' view of both conflicts as the same one.

Similarly, in 'Love Letter From Spain,' when Johnny writes “Fascists is Jim Crow peoples, honey_/And here we shoot “em down” (Hughes 2011, vv.21-22), he is expressing in what Isabel Soto calls an "epistemological and an aesthetic positioning” (2014: 140) his pride in fighting Fascism, and equates it with the segregation system back in Alabama and many other States. By physically combating Franco's troops, 
Johnny feels he is metaphorically fighting the ideology behind racist structures and practices in his own homeland. This same identification runs throughout several other Langston Hughes poems, even those he wrote years after the conflict. In 'From Spain To Alabama,' for instance, he draws a clear parallelism between flamenco-which he previously identified as "the song of Spain" in a poem written during the conflict—and blues in order to highlight that the people's problems in both spaces referred to by those types of music (Spain and Alabama, respectively) were alike:

What is the song of Spain?

Flamenco is the song of Spain:

Gypsies, guitars, dancing

Death and love and heartbreak

To a heel tap and a swirl of fingers

On three strings.

Flamenco is the song of Spain.

(Hughes, “Song Of Spain” vv.3-10)
Where have the people gone

That they do not sing

Their flamencos?

The people

Have gone nowhere:

They still sing

Their flamencos.

Where have the people gone

That they do not sing

Their blues?

The people

Have gone nowhere:

They still sing

Their blues.

(Hughes, "From Spain To Alabama”) 
It is not the first time that Hughes establishes such a direct link between both forms of music as a metaphor for what he perceives to be a parallelism between the suffering of the colored people in the US and that of Spanish gypsies (Moreno 2006) or rather, I argue, all oppressed Spaniards during the Spanish Civil War and later fascist regime. In I Wonder as I Wander, Hughes mentions that he attended a performance of Pastora Pavón (“La Niña de los Peines”viii), a famous Spanish flamenco singer at the time in which Hughes visited the country, and describes his feelings towards the show in the following terms: "I found the strange, high, wild crying of her flamenco in some ways much like the primitive Negro blues of the deep South. The words and music were filled with heartbreak, yet vibrant with resistance to defeat, and hard with the will to savor life in spite of its vicissitudes" (1993: 333). This view of the performance of "this old Girl with the Combs" as "vibrant with resistance to defeat" is concordant with Hughes's consistent portrayal of the fight in Spain as an undeterred resistance to fascism and oppression as seen in the poems above, and his references to heartbreak and blues highlight his constant translation and identification of that fight with the racial struggle of African Americans.

Likewise, in 'Tomorrow's Seed,' also written after the conflict, Hughes recaptures Johnny’s hope for a better future for African Americans as derived from the opposition to Fascism in Spanish soil expressed in the 1938 poem 'Postcard From Spain,' and maintains that the bodies of African American soldiers “Stuck deep in Spanish earth” will become "Human seed/For freedom’s birth” (Hughes 1995f, vv.1920), a theme that also resonates through 'Negro-International Brigade,' another poem on the Spanish Civil War written after the event:

But had I lived for score and ten 
Life could not've had

A better end.

I’ve given what I wished

And what I had to give

That others live. (Hughes 1995c, vv.23-28)

Those “others” are clearly the soldier’s fellow African Americans at home. Thus, he conceives his sacrifice as not made merely for the people of Spain, but for all peoples of color; precisely all those that Hughes claimed to be writing for.

As we can see, the political, racial and cultural parallels between the Spanish conflict and the situation in the US that Hughes drew from his experience in the Spanish Civil War accompanied him long after he left the country, and, upon departure, he was burdened by much more than mere objects and souvenirs. Placed in a position of intermediary between two countries, two cultures and two experiences, Hughes acts as conduit for the experience of one culture to flow onto the understanding of the other and back again, bringing with itself traces of the latter on the return trip. Both in his own writings about the Spanish Civil War and in his choice of texts for translation, Hughes embodies the true figure of the translator as mediator, as the agent who connects and relates languages and ways of thinking. This results in a notional if not purely linguistic translation process during which both poles mutually partake of the unavoidable transference that takes place. This is how both translation and literature become truly transnational and transcultural. 


\section{WORKS CITED:}

De Santis, Christopher C. 2013. "Reassessing Langston Hughes and the Harlem renaissance: Toward an African American aesthetic.” Critical Insights. Langston Hughes, edited by R. Baxter Miller, Salem Press, pp. 105-120.

Edwards, Brent Hayes 2007. "Langston Hughes and the Futures of Diaspora.” American Literary History, vol.19, no. 3, pp. 689-711.

García Luque, Antonio 1936. “El moro fugado.” Romancero de la guerra civil, edited by Francisco Caudet, 1978, Ediciones de la torre, p. 146.

Girón Echevarría, Luis 2005. “Langston Hughes’s Spanish Civil War Verse.” Anuario de Estudios Filológicos, vol. 28, pp. 91-101.

Hughes, Langston 1937. “Too much of race.” The Crisis, vol. 44, no. 9, p. 272.

--- 1993. I wonder as I wander. Hill and Wang.

--- 1995a. “From Spain To Alabama.” The collected poems of Langston Hughes, edited by Arnold Rampersad and David Roessel, Vintage, pp. 352-353.

--- 1995b. “Letter From Spain.” The collected poems of Langston Hughes, edited by Arnold Rampersad and David Roessel, Vintage, pp. 201-202.

--- 1995c. “Negro-International Brigade.” The collected poems of Langston Hughes, edited by Arnold Rampersad and David Roessel, Vintage, pp. 431-432.

---1995d. "Postcard From Spain.” The collected poems of Langston Hughes, edited by 
Arnold Rampersad and David Roessel, Vintage, pp. 202-203.

--- 1995e. “Song Of Spain.” The collected poems of Langston Hughes, edited by Arnold Rampersad and David Roessel, Vintage, pp. 195-197.

--- 1995f. “Tomorrow’s Seed.” The Collected Poems of Langston Hughes, edited by Arnold Rampersad and David Roessel, Vintage, p. 431.

--- 2002a. "Fighters from other lands look to Ohio man for food." The collected works of Langston Hughes. Essays on art, race, politics and world affairs. Vol. 9, edited by Christopher C. De Santis, University of Missouri Press, pp. 185-187.

--- 2002b. “Howard man fighting as Spanish Loyalist.” The collected works of Langston Hughes. Essays on art, race, politics and world affairs. Vol. 9, edited by Christopher C. De Santis, University of Missouri Press, pp. 194-195.

--- 2002c. "Hughes finds moors being used as pawns by Fascists in Spain.” The collected works of Langston Hughes. Essays on art, race, politics and world affairs. Vol. 9, edited by Christopher C. De Santis, University of Missouri Press, pp. 161-165.

--- 2002d. "Milt Herndon died trying to rescue wounded pal." The collected works of Langston Hughes. Essays on art, race, politics and world affairs. Vol. 9, edited by Christopher C. De Santis, University of Missouri Press, pp. 181-185.

--- 2002e. “Negroes in Spain.” The collected works of Langston Hughes. Essays on art, race, politics and world affairs. Vol. 9, edited by Christopher C. De Santis, 
University of Missouri Press, pp. 156-158.

--- 2002 f. "Pittsburg soldier hero, but too bashful to talk." The collected works of Langston Hughes. Essays on art, race, politics and world affairs. Vol. 9, edited by Christopher C. De Santis, University of Missouri Press, pp. 187-189.

--- 2002g. "Soldiers from many lands united in Spanish fight." The collected works of Langston Hughes. Essays on art, race, politics and world affairs. Vol. 9, edited by Christopher C. De Santis, University of Missouri Press, pp. 178-181.

--- 2011. “Love letter from Spain.” Escritos sobre España, La Oficina, pp. 236-238.

Izarra, Laura P. Z. 2004. “Locations and identities in Irish diasporic narratives,” HJEAS. Hungarian Journal of English and American Studies, vol. 10 no. 1-2, pp. 341352.

Miller, R. Baxter and Dolan Hubbard 2013. “The critical reception of Langston Hughes, 1924-2012.” Critical insights. Langston Hughes, edited by R. Baxter Miller, Salem Press, pp. 31-54.

Moreno, María Paz 2006. "Gypsy moon over Harlem: the intertwined voices of Langston Hughes and Federico García Lorcá.” Langston Hughes Review, vol. 20, pp. 17-33.

Scaramella, Evelyn 2014. “Translating the Spanish Civil War: Langston Hughes’s transnational poetics.” The Massachusetts Review, vol. 55, no. 2, pp. 177-188.

Scott, William 2005. “'Motivos’ of Translation. Nicolás Guillén and Langston Hughes.” 
CR: The New Centennial Review, vol. 5 no. 2, pp. 35-71.

Soto, Isabel 2014. “'I knew that Spain once belonged to the moors’: Langston Hughes, race, and the Spanish Civil War.” Research in African Literatures, vol. 45, no. 3, pp. 130-146.

\footnotetext{
${ }^{\mathrm{i}}$ Even though the Spanish Civil War started with the Nationalist uprising in Melilla on July $17^{\text {th }} 1936$ and spread almost immediately throughout the Spanish protectorate in Morocco before jumping to the peninsula on the following day, Langston Hughes makes no reference to nor links this fact with General Franco's use of Moroccan troops (regulares) or Moorish mercenary soldiers in any of his writings about the conflict.

ii From one moment to another (Poetry and History) 1932-1937

iii The Alianza de Intelectuales Antifascistas (Alliance of Antifascist Intellectuals) was a Spanish institute founded by Rafael Alberti as a refuge and support for Republican artists and their works-very much in the same way as The Crisis was the literary manifestation of the NCAAP.

${ }^{\text {iv }}$ Poets in loyalist Spain

${ }^{v}$ Ballads of the Spanish Civil War

${ }^{v i}$ It would not have been the first; Alberti had already asked Hughes to translate Federico García Lorca's Romancero gitano into English. Hughes did, and in 1951 the Gipsy ballads were published in the Beloit Poetry Journal. He also produced a translation of Lorca's play Bodas de sangre (Blood wedding).

vii In the original, this verse reads as "yo estar rojo, camaradas" (García Luque 1936, v.21). The fact that García Luque makes the moor's speech grammatically incorrect (it should be yo soy rojo), represents once again the linguistic as well as ideological barrier between these moors and the Loyalist Spaniards that Hughes also features in his writings. In the translation, however, this is lost.

viii which literally translates as "the girl of the combs."
} 